\title{
Fungicide application can improve production of tomato coinfected with Begomovirus and Crinivirus
}

\author{
Leysimar Ribeiro Pitzr Guimarães(1), Denise Nakada Nozaki(1), Mônika Fecury Moura(1), \\ David Marques de Almeida Spadotti ${ }^{(1)}$, Tatiana Mituti(2), Renate Krause-Sakate ${ }^{(1)}$ and Marcelo Agenor Pavan ${ }^{(1)}$ \\ (1)Universidade Estadual Paulista Júlio de Mesquita Filho, Faculdade de Ciências Agronômicas, Departamento de Proteção Vegetal, Rua \\ José Barbosa de Barros, no 1.780, CEP 18610-370 Botucatu, SP, Brazil. E-mail: leysimarpitzr@yahoo.com.br, denozaki@hotmail.com, \\ agromonika@yahoo.com.br, dspadotti@gmail.com, renatekrause@fca.unesp.br, mapavan@fca.unesp.br (2)Universidade de São Paulo, \\ Escola Superior de Agricultura Luiz de Queiroz, Departamento de Fitopatologia e Nematologia, Avenida Pádua Dias, № 11, CEP 13418-900 \\ Piracicaba, SP, Brazil. E-mail: tatiana.mituti@gmail.com
}

Abstract - The objective of this work was to evaluate the effect of fungicide application on the concentration of Tomato severe rugose virus (ToSRV, Begomovirus) in the 'Mariana' hybrid tomato coinfected with ToSRV and Tomato chlorosis virus (ToCV, Crinivirus) and the progression of viral concentration by qPCR, as well as to quantify fruit yield and quality. Experiment I consisted in the application of fungicides after sowing (pretreatment): pyraclostrobin+metiram $(\mathrm{P}+\mathrm{M})\left(\right.$ at $\left.3 \mathrm{~g} \mathrm{~L}^{-1}\right)+$ boscalid (B) (at $\left.0.3 \mathrm{~g} \mathrm{~L}^{-1}\right)$, followed by biweekly sprayings with $\mathrm{P}+\mathrm{M}\left(4 \mathrm{~g} \mathrm{~L}^{-1}\right)$; in experiment II, there was no application at sowing (control treatment), only 4 $\mathrm{g} \mathrm{L}^{-1} \mathrm{P}+\mathrm{M}$ biweekly. ToSRV and ToCV transmissions were performed using sweetpotato whiteflies (Bemisia tabaci, biotype B), at 15, 30, 45, 60, and 70 days after transplanting (DAT). There was an increase in yield, better fruit quality, and a reduction in the ToSRV concentration in the plants, when the viruses were transmitted late and pretreatment was performed. Tray pretreatment in sowing with $\mathrm{P}+\mathrm{M}\left(3 \mathrm{~g} \mathrm{~L}^{-1}\right)$ and $\mathrm{B}\left(0.3 \mathrm{~g} \mathrm{~L}^{-1}\right)$, followed by biweekly sprayings with $\mathrm{P}+\mathrm{M}\left(4 \mathrm{~g} \mathrm{~L}^{-1}\right)$, increases fruit yield and quality in the 'Mariana' hybrid tomato coinfected at 45, 60, and 75 DAT by ToSRV and ToCV, and there is a reduction in the concentration of ToSRV.

Index terms: Solanum lycopersicum, boscalid, metiram, pyraclostrobin, ToCV, ToSRV.

\section{A aplicação de fungicidas pode incrementar a produção de tomateiro coinfectado por Begomovirus e Crinivirus}

Resumo - O objetivo deste trabalho foi avaliar o efeito da aplicação de fungicidas na concentração de Tomato severe rugose virus (ToSRV, Begomovirus) no híbrido de tomateiro 'Mariana' coinfectado por ToSRV e Tomato chlorosis virus (ToCV, Crinivirus) e a progressão da concentração viral por qPCR, bem como quantificar a produção e a qualidade de frutos. O experimento I consistiu na aplicação dos fungicidas após a semeadura (prétratamento): piraclostrobina+metiram $(\mathrm{P}+\mathrm{M})\left(\mathrm{a} 3 \mathrm{~g} \mathrm{~L}^{-1}\right)+$ boscalida (B) $\left(\right.$ a $\left.0,3 \mathrm{~g} \mathrm{~L}^{-1}\right)$, seguida de pulverizações quinzenais com $\mathrm{P}+\mathrm{M}\left(4 \mathrm{~g} \mathrm{~L}^{-1}\right)$; no experimento II, não houve aplicação na semeadura (controle), apenas 4 $\mathrm{g} \mathrm{L}^{-1}$ de $\mathrm{P}+\mathrm{M}$ quinzenalmente. As transmissões de ToSRV e ToCV foram realizadas com uso de moscasbrancas (Bemisia tabaci, biótipo B), aos 15, 30, 45, 60 e 70 dias após o transplante (DAT). Houve aumento da produção, melhor qualidade dos frutos e redução da concentração de ToSRV nas plantas, quando os vírus foram transmitidos tardiamente e o pré-tratamento foi realizado. O pré-tratamento na bandeja, na semeadura, com $\mathrm{P}+\mathrm{M}\left(3 \mathrm{~g} \mathrm{~L}^{-1}\right)$ e $\mathrm{B}\left(0,3 \mathrm{~g} \mathrm{~L}^{-1}\right)$, seguido de pulverizações quinzenais com $\mathrm{P}+\mathrm{M}\left(4 \mathrm{~g} \mathrm{~L}^{-1}\right)$, aumenta a produção e a qualidade dos frutos, em tomateiro híbrido 'Mariana' coinfectado aos 45, 60 e 75 DAT por ToSRV e ToCV, e há redução da concentração de ToSRV.

Termos para indexação: Solanum lycopersicum, boscalida, metiram, piraclostrobina, ToCV, ToSRV.

\section{Introduction}

Tomato (Solanum lycopersicum L.) is one of the most highly cultivated vegetables in Brazil and worldwide. However, it is subject to various phytosanitary problems, including viruses transmitted by whitefly (Inoue-Nagata et al., 2016).
The species Tomato severe rugose virus (ToSRV) belongs to the genus Begomovirus and is transmitted in a persistent/circulative, non-propagative manner by Bemisia tabaci, biotype B (Gennadius, 1889) (Hemiptera: Aleyrodidae) (Polston et al., 2014), whereas the species Tomato chlorosis virus (ToCV), which belongs to the genus Crinivirus, is transmitted 
by two different genera of the Aleyrodidae family, Bemisia (B. tabaci) and Trialeurodes (T. vaporariorum and $T$. abutilonea), via semi-persistent/non-circulative transmission (Wintermantel \& Wisler, 2006). ToSRV is currently the predominant species of begomovirus in Midwestern-Southern Brazil and there is frequently coinfection of this virus with ToCV (Barbosa et al., 2011; Macedo et al., 2014; Inoue-Nagata et al., 2016).

One of the methods used to manage these viruses is insecticide application to control the vector Aleyrodidae; however, this is not an efficient method for virus control. Additionally, constant use of the same active ingredient favors the selection and multiplication of resistant populations (Esashika et al., 2016; Inoue-Nagata et al., 2016). Another strategy is to promote sanitary emptiness conditions, as occurs in the state of Goiás, Brazil, in which the producer may transplant tomato seedlings in the field only between February 1 and June 30, and harvesting must be necessarily completed in November. Between December and January, there is no tomato planting (Agrodefesa, 2011). The period without planting has a positive effect, since it delays the appearance of the virus during the early stages of crop growth, when the plants are more susceptible to infection (Inoue-Nagata et al., 2016).

Currently, imported commercial tomato hybrid seeds containing $T y-1, T y-2, T y-3, T y-4$, and $T y-5$ genes are available, which promote resistance to begomoviruses reported in tomato (Hutton et al., 2012); however, it is important to emphasize that these genes do not always offer effective resistance to Brazilian begomovirus isolates (Inoue-Nagata et al., 2016).

Chemicals that alter plant physiology have been studied as a new strategy to control plant diseases because they activate defense mechanisms that reduce the disease incidence in different pathosystems (Udayashankar et al., 2012; Guimarães et al., 2014; Itako et al., 2015; Skandalis et al., 2016). However, little information is available on how these chemicals induce the resistance mechanisms that lead to control of viruses in tomato plants.

The objective of this work was to evaluate the effect of fungicide application on the concentration of Tomato severe rugose virus (ToSRV, Begomovirus) in 'Mariana' tomato hybrid coinfected with ToSRV and Tomato chlorosis virus (ToCV, Crinivirus) and the progression of viral concentration by qPCR, as well as to quantify fruit yield and quality.

\section{Materials and Methods}

The experiments were conducted in a greenhouse at the department of plant protection of Faculdade de Ciências Agronômicas, of Universidade Estadual Paulista Júlio de Mesquita Filho, in the municipality of Botucatu, in the state of São Paulo, Brazil. Tomato seedlings, all at the same growth stage and grown for in natura consumption, obtained from seeds of the tomato hybrid 'Mariana' were used (Sakata, Bragança Paulista, SP, Brazil). Two parallel experiments using the combined application of fungicides pyraclostrobin + metiram $(\mathrm{P}+\mathrm{M})($ Cabrio Top, BASF $)$ + boscalid (B) (Cantus, BASF, Guaratinguetá, SP, Brazil) were evaluated. In experiment I, fungicides were applied after sowing - pretreatment: $\mathrm{P}+\mathrm{M}$ $\left(3 \mathrm{~g} \mathrm{~L}^{-1}\right)+\mathrm{B}\left(0.3 \mathrm{~g} \mathrm{~L}^{-1}\right)$, followed by biweekly spraying of the seedlings with $\mathrm{P}+\mathrm{M}\left(4 \mathrm{~g} \mathrm{~L}^{-1}\right)$. In experiment II, the tomato seedlings were not treated at sowing (control), but were subjected to the biweekly applications of $4 \mathrm{~g} \mathrm{~L}^{-1} \mathrm{P}+\mathrm{M}$. The fungicides were applied following the manufacturer's recommendations, and there were four biweekly applications in total. A randomized complete block design, consisting of six treatments, was used: five experimental transmissions using Bemisia tabaci (MEAM1 species, biotype B) at 15, 30, 45, 60, and 75 days after transplanting (DAT), and a control without inoculation. There were five replicates for each treatment.

The source of inoculum for the transmission by $B$. tabaci used in the experiment was tomato plants that had been infected with a mix of ToSRV and ToCV. For this purpose, twenty specimens of $B$. tabaci (biotype B) were used per plant, with periods of acquisition (PAA) and inoculation (PAI) of $48 \mathrm{~h}$ each. After PAI, the plants were sprayed with the insecticide thiamethoxam ( $2 \mathrm{~g} \mathrm{~L}^{-1}$; Syngenta) and the evaluation of the transmission rates was performed biweekly until the end of the experiment.

The fungicide application efficiency and yield results were subjected to normality and homogeneity tests, and the average values were compared using the Tukey's test at $5 \%$ probability level. Statistical analyses were performed using the Sisvar program (Ferreira, 2011).

The ToSRV was detected by collecting leaf fragments from each plant, which were then used for total DNA extraction using a DNeasy Mini Plant kit (Qiagen, Hilden, Germany). This procedure was undertaken every 15 days after the transmission 
stages and continued until the end of the experiments. The extracted DNA was subjected to the rollingcircle amplification (RCA) technique as described by Inoue-Nagata et al. (2004) and Haible et al. (2006). A TempliPhi DNA Amplification kit (GE Healthcare, USA) was used for this procedure. The RCA product was analyzed by the polymerase chain reaction (PCR) using a PCR Master Mix kit (Promega, São Paulo, SP, Brazil) and the PALIv1978 and PAR1c496 oligonucleotides described by Rojas et al. (1993).

The ToCV was detected by total RNA extraction using Trizol LS (Invitrogen, São Paulo, SP, Brazil). Symptomatic leaves from each plant were collected, and extractions were performed every 15 days after inoculation until the end of the crop cycle. To confirm ToCV transmission, the nested reverse transcriptase polymerase chain reaction technique (Nested-RTPCR) was used with the primer pairs HS-11/HS-12 and TOC-5/TOC-6, as described by Dovas et al. (2002). The PCR products were analyzed on $1 \%$ agarose gel stained with Neo taq Brilliant Green Plus DNA Stain (Neobio, Botucatu, SP, Brazil).

The ToSRV and ToCV in the mixed infection were quantified using the real time quantitative PCR (qPCR) technique, which determined the standard curve using serial dilutions of DNA amplified by RCA. The DNA had been previously quantified using a spectrophotometer (Nanodrop, Wilmington, DE, USA) and the dilution concentrations were 100, 50, 25, 12.5 , and $6.25 \mathrm{ng} \mu \mathrm{L}^{-1}$. The correlation coefficient of the dilution curve was $90.62 \%$. The specific primers ToSRV (+) TAAAGTGATTGTCTGTGGCCC/ToRSV (-) CCGTTTAACAACTTGGGCCT were used at a $600-\mathrm{nM}$ concentration to amplify the desired DNA fragments. An absolute quantification of the viral DNA copies from plants that received inoculations at $15,30,45,60$, and 75 DAT was performed every 15 days after virus inoculation. The qPCR reactions were carried out in MicroAmp 96-well plates (Life Technologies, Waltham, MA, USA) in triplicate using the SYBR Green GoTaq qPCR Master Mix (Promega) with a final volume of $25 \mu \mathrm{L}$, following the manufacturer's instructions for Step One Plus RealTime PCR System (Applied Biosystems, São Paulo, $\mathrm{SP}$, Brazil). The qPCR reactions were carried out using the following protocol: initial denaturation at $95^{\circ} \mathrm{C}$ for $2 \mathrm{~min}$, followed by 40 cycles of $95^{\circ} \mathrm{C}$ for $15 \mathrm{~s}$, and then $60^{\circ} \mathrm{C}$ for $1 \mathrm{~min}$.
The treatment efficiency was evaluated at 90 DAT. The total fruit yield (average number of fruits per plant), average fruit weight (average of ten harvested fruits), and ratio of number of green fruits (total number of green fruits/total number of fruits) were recorded. The physicochemical characteristics of the fruits produced were also analyzed, such as total soluble solids ( ${ }^{\circ}$ Brix) (Horwitz et al., 1970) and titratable acidity, to obtain the proportion of total soluble solids (SS)/titratable acidity (TA) (Zenebon et al., 2008).

\section{Results and Discussion}

Considering the development stage of the 'Mariana' tomato hybrid, and the transmission efficiency, it was found that all plants (sprayed and control) in the 15, 30 , and 45 DAT treatments showed coinfection with ToSRV and ToCV. At 60 DAT, $60 \%$ of the plants that received the pretreatment (experiment I) were infected by ToSRV and ToCV, whereas $80 \%$ of the plants that did not receive the pretreatment (experiment II) showed symptoms. In the 75 DAT treatment, the treated plants remained asymptomatic until the end of the evaluation. The ToSRV could not be detected with conventional PCR, but could be with qPCR $\left(4.10 \times 10^{-6}\right.$ $\left.6.81 \times 10^{-6} \mathrm{ng} \mu \mathrm{L}^{-1}\right)$, with a mean cycle threshold $(\mathrm{Ct})$ of 28 , which was determined by the intersection of the reaction detection threshold line with the gene amplification line of each sample. The $\mathrm{Ct}$ value for the negative control ranged from 30 to 32 . For ToCV, the qPCR was not representative because the primer pair was not very efficient. The presence of ToCV could only be confirmed by Nested-RT-PCR.

The most severe symptoms, such as plant underdevelopment, intense chlorosis, and foliar wrinkling, were observed in the plants that had been infected at 15 and 30 DAT, and the plants in both treatments did not produce commercial-quality fruits (Tables 1 and 2). The plant responses were variable in the 45 and 60 DAT treatments. Some plants were asymptomatic or with symptoms visible only on the apical parts, and although mixed infection by ToSRV and $\mathrm{ToCV}$ was detected, the fruit yield and quality was better (Tables 1 and 2). The plants that received inoculations at 45, 60, and 75 DAT, in experiment I, showed better development characteristics and increased fruit yield. Furthermore, they did not differ statistically from uninoculated plants (Table 1).

Pesq. agropec. bras., Brasília, v.52, n.6, p.435-442, jun. 2017 DOI: 10.1590/S0100-204X2017000600007 
Over time, plant modifications, such as cell wall thickening and lignin formation, occur, which may influence cell-to-cell transmission, transmission, and long-distance transmission of the viruses (Balamuralikrishnan et al., 2003). Age-related resistance (ARR) has already been observed in several pathosystems (Develey-Rivière \& Galiana, 2007). This type of resistance is considered a distinct defense response of the plant, unlike systemically acquired resistance (SAR) and induced systemic resistance (ISR), and is related to the accumulation of salicylic acid (Kus et al., 2002). Previously, the effects of plant age on virus infection were observed in the following pathosystems: Maize dwarf mosaic virus (MDMV, Potyvirus) in different hybrids of Sorghum bicolor (sorghum) (Rangel et al., 1996), Sugarcane mosaic virus (SCMV, Potyvirus) in Saccharum officinarum (sugarcane) (Balamuralikrishnan et al., 2003), Cotton leaf curl virus (CLCuV, Begomovirus) in Gossypium hirsutum (cotton) (Akhtar et al., 2004), and Cucumber mosaic virus (CMV, Cucumovirus) and Potato virus $Y$ (PVY, Potyvirus) in Solanum lycopersicum (tomato) (Skandalis et al., 2016). These studies reinforced the idea that phenologically older plants show fewer symptoms, and that infection occurs more slowly than in younger plants.

The same behavior was verified in experiment II, where the 'Mariana' hybrid tomato seedlings did not receive the fungicide pretreatment after sowing (Table 2). The tomato plants that were subjected to fungicide applications throughout the crop cycle produced higher yields than those that did not receive any treatment. The yields from the plants that had been infected with ToSRV and ToCV at 45, 60, and 75 DAT were similar to those from uninfected plants (Tables 1 and 2).

The fungicide application after sowing (pretreatment), followed by biweekly spraying of $\mathrm{P}+\mathrm{M}$ during the crop cycle, had positive effects on the characteristics of tomato plants and seedling characteristics, fruit weight, and fruit yield, compared to the other treatments (Tables 1 and 2). The effect of $\mathrm{P}+\mathrm{M}$ was verified by the development of the seedlings treated shortly after transplantation, which showed a mean height of $11.2 \mathrm{~cm}$, which was higher than that of the control plants $(7.3 \mathrm{~cm})$.

The combination of formulations such as $\mathrm{P}+\mathrm{M}$, which belong to the strobilurin and dithiocarbamate classes of fungicides, has active principles with several synthetic compounds with a variety of synthetic compounds, showing antifungal activity with broad spectrum of action (Kozlowski et al., 2009). In addition to acting directly on the pathogen, they stimulate physiological effects highly beneficial to the plants, which result in increased photosynthesis and increased nitrate reductase enzyme activity, and reduced ethylene synthesis. All these factors contribute to the increase in fruit yield and quality (Fagan et al., 2010; Jadoski et al., 2015).

The plants treated with $\mathrm{P}+\mathrm{M}\left(4 \mathrm{~g} \mathrm{~L}^{-1}\right)$ at 45,60 , and 75 DAT showed lower amounts of green fruits, which

Table 1. Effect of application of pyraclostrobin + metiram to 'Mariana' hybrid tomato (Solanum lycopersicum) infected with ToSRV and ToCV at different growth points (treatments), on total production, fruit weight, percentage of green fruits, and the SS/TA ratio (soluble solids/titratable acidity) for plants that received a pretreatment (after sowing) with 3

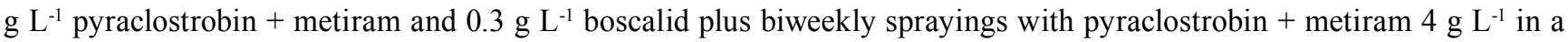
greenhouse located in the municipality of Botucatu, in the state of São Paulo, Brazil ${ }^{(1)}$.

\begin{tabular}{|c|c|c|c|c|c|c|c|c|c|c|c|c|}
\hline \multirow[t]{2}{*}{ Treatment } & \multicolumn{3}{|c|}{ Total production (kg per plant) } & \multicolumn{3}{|c|}{ Fruit weight $(\mathrm{g})$} & \multicolumn{3}{|c|}{ Green fruits $(\%)$} & \multicolumn{3}{|c|}{ SS/TA ratio } \\
\hline & $\begin{array}{c}\text { With } \\
\text { application }\end{array}$ & $\begin{array}{c}\text { Without } \\
\text { application }\end{array}$ & Average & $\begin{array}{c}\text { With } \\
\text { application }\end{array}$ & $\begin{array}{c}\text { Without } \\
\text { application }\end{array}$ & Average & $\begin{array}{c}\text { With } \\
\text { application }\end{array}$ & $\begin{array}{c}\text { Without } \\
\text { application }\end{array}$ & Average & $\begin{array}{c}\text { With } \\
\text { application }\end{array}$ & $\begin{array}{c}\text { Without } \\
\text { application }\end{array}$ & Average \\
\hline $15 \mathrm{DAT}$ & $1.39 \pm 0.09$ & $1.11 \pm 0.18$ & $1.25 \mathrm{~b}$ & $34.36 \pm 3.65$ & $29.80 \pm 3.29$ & $32.08 \mathrm{c}$ & $54.24 \pm 5.61$ & $70.31 \pm 8.11$ & $62.27 \mathrm{a}$ & $4.88 \pm 0.20$ & $6.57 \pm 0.37$ & $5.72 b$ \\
\hline 30 DAT & $1.92 \pm 0.20$ & $1.30 \pm 0.21$ & $1.61 b$ & $50.18 \pm 2.19$ & $38.38 \pm 3.79$ & $44.28 b$ & $62.46 \pm 6.65$ & $66.07 \pm 8.71$ & $64.26 \mathrm{a}$ & $6.29 \pm 0.44$ & $6.93 \pm 0.14$ & 6.61ab \\
\hline 45 DAT & $2.51 \pm 0.08$ & $1.68 \pm 0.07$ & $2.10 \mathrm{a}$ & $59.09 \pm 3.08$ & $39.94 \pm 4.30$ & $49.51 \mathrm{ab}$ & $40.74 \pm 6.93$ & $50.34 \pm 2.89$ & $45.54 \mathrm{ab}$ & $7.35 \pm 0.53$ & $7.19 \pm 0.07$ & $7.27 \mathrm{a}$ \\
\hline 60 DAT & $2.43 \pm 0.20$ & $1.96 \pm 0.14$ & $2.20 \mathrm{a}$ & $55.01 \pm 1.78$ & $42.27 \pm 2.48$ & $48.64 \mathrm{ab}$ & $35.64 \pm 2.36$ & $43.55 \pm 4.42$ & $39.60 \mathrm{~b}$ & $7.40 \pm 0.20$ & $7.13 \pm 0.25$ & $7.27 \mathrm{a}$ \\
\hline 75 DAT & $2.58 \pm 0.05$ & $2.23 \pm 0.05$ & $2.40 \mathrm{a}$ & $66.0 \pm 2.77$ & $42.69 \pm 3.27$ & $54.38 \mathrm{a}$ & $35.26 \pm 2.13$ & $40.83 \pm 3.53$ & $38.04 \mathrm{~b}$ & $7.63 \pm 0.62$ & $7.21 \pm 0.45$ & $7.42 \mathrm{a}$ \\
\hline Without virus & $2.26 \pm 0.03$ & $2.33 \pm 0.08$ & $2.30 \mathrm{a}$ & $62.50 \pm 2.84$ & $52.54 \pm 1.69$ & $57.52 \mathrm{a}$ & $34.80 \pm 1.54$ & $34.22 \pm 1.84$ & $34.51 \mathrm{~b}$ & $7.65 \pm 0.25$ & $7.55 \pm 0.31$ & $7.60 \mathrm{a}$ \\
\hline Average & $2.18 \mathrm{~A}$ & $1.77 \mathrm{~B}$ & - & $54.53 \mathrm{~A}$ & 40.94B & - & $43.86 \mathrm{~B}$ & $50.88 \mathrm{~A}$ & - & 6.87 & 7.10 & - \\
\hline $\mathrm{P}(\mathrm{A})$ & & 0.0010 & & & 0.0010 & & & 0.0663 & & & 0.3192 & \\
\hline P (Treat.) & & 0.0010 & & & 0.0010 & & & 0.0010 & & & 0.0020 & \\
\hline $\mathrm{P}(\mathrm{A} \times$ Treat. $)$ & & 0.0750 & & & 0.0980 & & & 0.8582 & & & 0.0896 & \\
\hline
\end{tabular}

${ }^{(1)}$ Averages followed by equal lower case letters in the columns and upper case letters in the rows do not differ significantly by Tukey's test, at $5 \%$ probability. A, application of fungicides; and DAT, days after transplantation. 


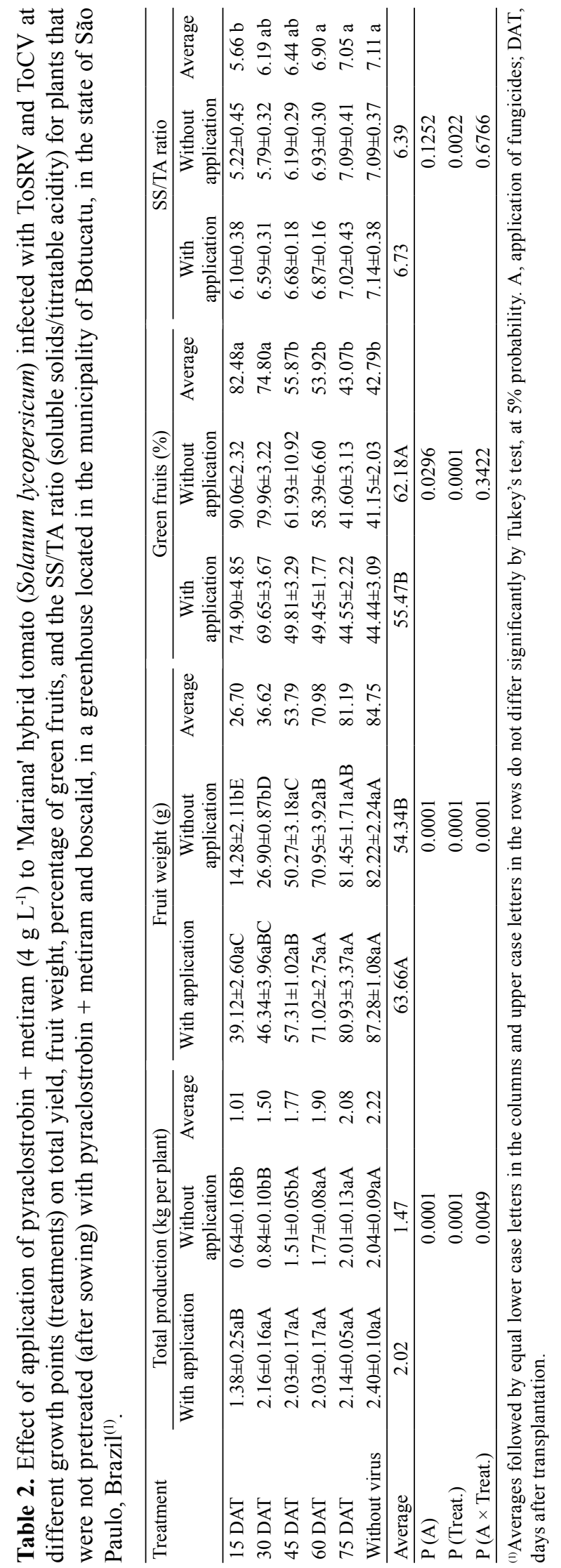

suggested that the application of these fungicides during the crop cycle may have induced maturation uniformity (Tables 1 and 2). The physiological effects of strobilurins have already been observed on endogenous plant regulators. For example, they can alter the auxin, indoleacetic acid (IAA), and abscisic acid (ABA) levels in plants. Abscisic acid plays a similar role to ethylene, and affects the maturation and senescence of the fruits. Therefore, it is considered a regulator of maturation control because the concentration of this hormone in green fruits is low and its presence can favor the maturation of climacteric and non-climacteric fruits (Zhang et al., 2009). In tomato, Bastías et al. (2011) found that $\mathrm{ABA}$ controls maturation and increases the levels of the soluble sugars that are essential to guarantee the quality and flavor of tomato fruits. In this study, an increase in the ratio (proportion) of fruits on late-inoculated plants and receiving $\mathrm{P}+\mathrm{M}$ application $\left(4 \mathrm{~g} \mathrm{~L}^{-1}\right)$ was observed (Tables 1 and 2). The SS/TA ratio (soluble solids/titratable acidity) describes the fruit flavor. The fruits from seedlings treated at sowing and from plants that received inoculations at 45, 60, and 75 DAT had higher SS/TA ratios than those treated at 15 and 30 DAT (Table 1). Equivalent results were obtained in the experiment without pretreatment at sowing (Table 2). It should be noted that for most of the analyzed factors, the application of $\mathrm{P}+\mathrm{M}$ throughout the crop cycle led to increased yields and fruit quality (Table 3 ).

A higher concentration rate of ToSRV was observed, ranging from 1.13 to $1.80 \mathrm{ng} \mu \mathrm{L}^{-1}$, in the plants that did not receive the pretreatment at sowing nor $\mathrm{P}+\mathrm{M}$ applications throughout the production cycle when the plants received inoculations at 30 and 90 days after inoculation (DAI) (Figure 1), respectively. Regardless of the phenological stage of the plant, during the transmission of ToRSV and ToCV, a more marked reduction in viral concentration was observed in plants that received the fungicide treatment soon after sowing, as well as during their production cycle (Figure 1). When the viruses were inoculated at 30 DAT, viral quantification was performed at 45, 60, 75, and 90 DAI (Figure 1 B). Plants without pretreatment, but that later received applications of fungicides, showed lower concentrations of ToSRV, which ranged from $0.75 \mathrm{ng} \mu \mathrm{L}^{-1}$ (45 DAI) to $0.95 \mathrm{ng} \mu \mathrm{L}^{-1}$ (90 DAI). The obtained results suggest that, in this phenological phase, fungicide application had an effect on viral concentration, regardless of whether the plant was 
Table 3. Joint analysis of the experiments on 'Mariana' hybrid tomato (Solanum lycopersicum) with or without pretreatment with pyraclostrobin + metiram $(\mathrm{P}+\mathrm{M})$ and boscalid $(\mathrm{B})$ in the trays after sowing in a greenhouse located in the municipality of Botucatu, in the state of São Paulo, Brazil ${ }^{(1)}$.

\begin{tabular}{|c|c|c|c|c|c|c|c|c|}
\hline \multirow[t]{2}{*}{ Factors } & \multicolumn{2}{|c|}{ Total production (kg per plant) } & \multicolumn{2}{|c|}{ Fruit weight $(\mathrm{g})$} & \multicolumn{2}{|c|}{ Green fruits (\%) } & \multicolumn{2}{|c|}{ SS/TA ratio } \\
\hline & $\begin{array}{c}\text { With } \\
\text { pretreatment }^{(2)}\end{array}$ & $\begin{array}{c}\text { Without } \\
\text { pretreatment }^{(3)}\end{array}$ & $\begin{array}{c}\text { With } \\
\text { pretreatment }\end{array}$ & $\begin{array}{c}\text { Without } \\
\text { pretreatment }\end{array}$ & $\begin{array}{c}\text { With } \\
\text { pretreatment }\end{array}$ & $\begin{array}{c}\text { Without } \\
\text { pretreatment }\end{array}$ & $\begin{array}{c}\text { With } \\
\text { pretreatment }\end{array}$ & $\begin{array}{c}\text { Without } \\
\text { pretreatmen }\end{array}$ \\
\hline With $\mathrm{P}+\mathrm{M}$ & $2.18 \mathrm{a}$ & $2.02 \mathrm{a}$ & $54.53 \mathrm{a}$ & $63.66 \mathrm{a}$ & $43.86 \mathrm{a}$ & $55.47 \mathrm{~b}$ & $6.87 \mathrm{a}$ & $6.73 a$ \\
\hline Without $\mathrm{P}+\mathrm{M}$ & $1.77 \mathrm{~b}$ & $1.47 \mathrm{~b}$ & $40.94 b$ & $54.34 \mathrm{~b}$ & $50.88 \mathrm{a}$ & $62.18 \mathrm{a}$ & $7.10 \mathrm{a}$ & $6.39 \mathrm{a}$ \\
\hline Average & 1.98 & 1.75 & 47.74 & 57.27 & 47.37 & 58.83 & 6.99 & 6.56 \\
\hline Standard deviation & 0.33 & 0.34 & 7.89 & 6.54 & 9.79 & 7.74 & 0.96 & 1.12 \\
\hline $\mathrm{CV}(\%)$ & 16.64 & 19.68 & 16.45 & 11.08 & 22.32 & 15.22 & 13.90 & 17.90 \\
\hline $\mathrm{P}(\mathrm{A})$ & 0.0023 & 0.0039 & 0.0043 & 0.0020 & 0.3650 & 0.0065 & 0.2800 & 0.5400 \\
\hline $\mathrm{P}$ (Treatments) & 0.0019 & 0.0016 & 0.0013 & 0.0013 & 0.0068 & 0.0018 & 0.0051 & 0.00398 \\
\hline $\mathrm{P}(\mathrm{A} \times$ Treatments $)$ & 0.2150 & 0.0038 & 0.1920 & 0.0084 & 0.5000 & 0.1480 & 0.2220 & 0.2500 \\
\hline
\end{tabular}

(1)Averages followed by equal letters, lower case in the columns and upper case in the rows, do not significantly differ by Tukey's test, at $5 \%$ probability. ${ }^{(2)}$ With pretreatment: $(\mathrm{P}+\mathrm{M})$ at $3 \mathrm{~g} \mathrm{~L}^{-1}$ and $(\mathrm{B})$ at $0.3 \mathrm{~g} \mathrm{~L}^{-1}$ in the tray, after sowing, followed by biweekly sprayings with $(\mathrm{P}+\mathrm{M})$ at $4 \mathrm{~g} \mathrm{~L}$ L $^{-1}{ }^{\left({ }^{3}\right)} \mathrm{Without}$ pretreatment: biweekly sprayings with $(\mathrm{P}+\mathrm{M})$ at $4 \mathrm{~g} \mathrm{~L}^{-1}$. CV, coefficient of variation. A, application of fungicides. Treatments: inoculation with ToSRV and $\mathrm{ToCV}$ at $15,30,45,60$, and 75 days after transplanting.
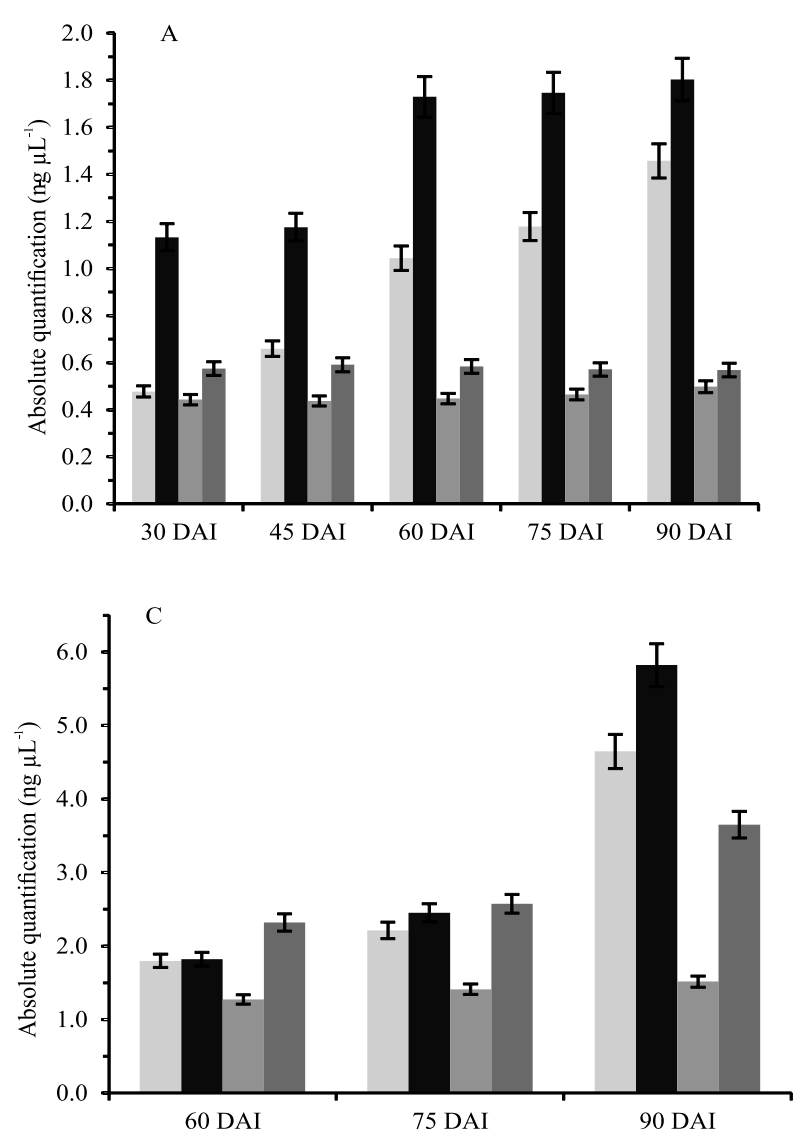
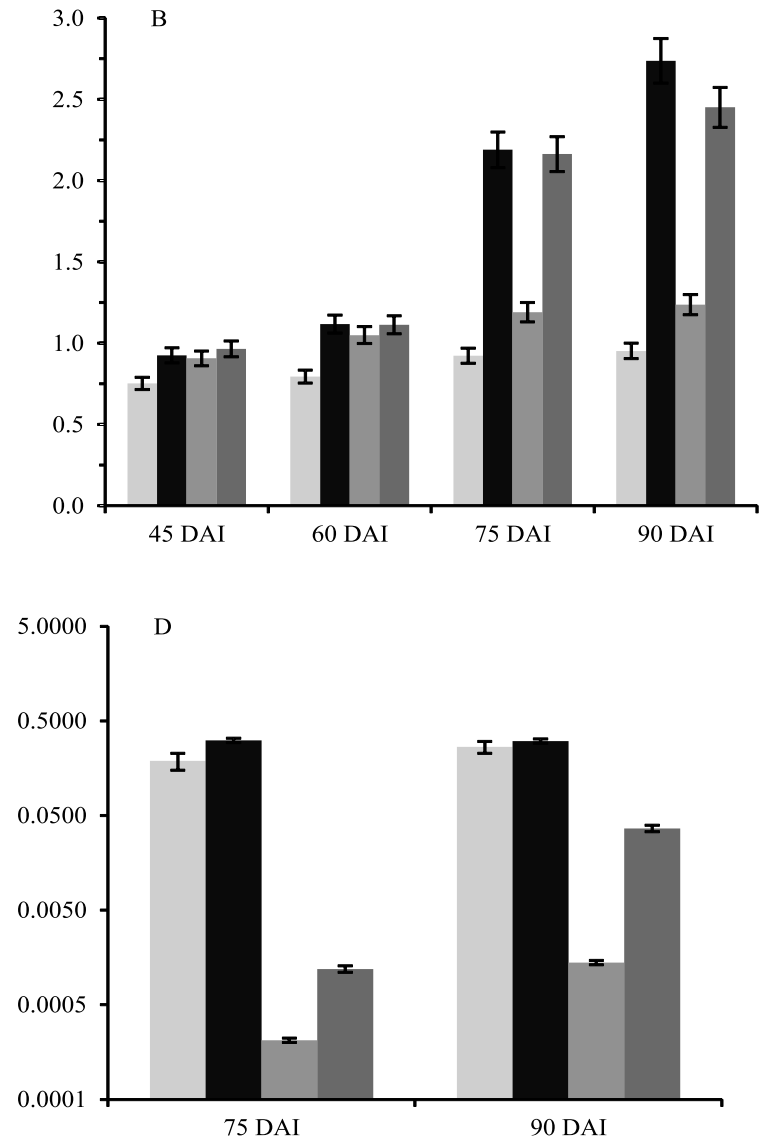

\begin{tabular}{|c|c|}
\hline $\begin{array}{l}\text { Without pretreat./ With } \mathrm{P}+\mathrm{M} 4 \mathrm{~g} \mathrm{~L}^{-1} \\
\text { With pretreat. / With } \mathrm{P}+\mathrm{M} 4 \mathrm{~g} \mathrm{~L}^{-1}\end{array}$ & $\begin{array}{l}\text { - Without pretreat./ Without } \mathrm{P}+\mathrm{M} 4 \mathrm{~g} \mathrm{~L}^{-1} \\
\text { With pretreat./Without } \mathrm{P}+\mathrm{M} 4 \mathrm{~g} \mathrm{~L}^{-1}\end{array}$ \\
\hline
\end{tabular}

Figure 1. Absolute quantification of Tomato severe rugose virus (ToSRV) in 'Mariana' hybrid tomato (Solanum lycopersicum). The inoculations were performed at: A, 15 days after transplantation (DAT); B, 30 DAT; C, 45 DAT; and D, 60 DAT. The $\mathrm{X}$-axis quantifications were performed at $15,30,45,60,75$, and 90 days after inoculation (DAI). Pretreatment: pyraclostrobin + metiram $(\mathrm{P}+\mathrm{M})$ at $3 \mathrm{~g} \mathrm{~L}^{-1}$, and boscalid at $0.3 \mathrm{~g} \mathrm{~L}^{-1}$ after sowing, plus biweekly sprayings with $\mathrm{P}+\mathrm{M} \mathrm{at} \mathrm{g} \mathrm{L}^{-1}$. 
subjected to pretreatment. Peak viral concentration occurred at 90 DAI in the plants that did not receive the pretreatment nor fungicide application over the crop cycle (Figure $1 \mathrm{~B}$ ).

The ToSRV concentration was quantified at 60,75 , and 90 days after inoculation in plants that received inoculations at 45 DAT (Figure $1 \mathrm{C}$ ). The highest quantification values were observed at $90 \mathrm{DAI}$, when the maximum concentration was $5.82 \mathrm{ng} \mu \mathrm{L}^{-1}$ and was recorded in plants without pretreatment at sowing and without applications of $\mathrm{P}+\mathrm{M}$ during the crop cycle. The lowest viral concentration was observed in plants subjected to pretreatment at sowing and applications of $\mathrm{P}+\mathrm{M}\left(1.28\right.$ and $1.52 \mathrm{ng} \mu \mathrm{L}^{-1}$, at 60 and $75 \mathrm{DAI}$, respectively) (Figure $1 \mathrm{C}$ ).

Plants that received inoculations at 60 DAT were quantified at 75 and 90 days after inoculation. A lower viral concentration rate was recorded for all treatments, especially for those that had received the pretreatment at sowing (Figure 1 D). Plants that received inoculations at $75 \mathrm{DAT}$ and were evaluated at 90 DAI had extremely low viral concentrations, with averages between $4.10 \times 10^{-6}$ and $6.81 \times 10^{-6} \mathrm{ng} \mu \mathrm{L}^{-1}$, which meant that virus detection was not possible by conventional PCR.

Previously, it has been reported that pepper plants subjected to biolistic inoculation with Pepper golden mosaic virus (PepGMV, Begomovirus) and treated with Benzothiadiazole (BTH) showed a 5-6-fold reduction in viral concentration compared to the untreated plants (Trejo-Saavedra et al., 2013). In the present study, an approximately 4-fold reduction in viral concentration was obtained for tomato plants that received inoculations with ToSRV and ToCV at 45 DAT and subjected to the pretreatment and biweekly sprayings compared to the viral concentration in untreated plants (Figure 1).

In general, the application of $\mathrm{P}+\mathrm{M}$ reduced the viral concentration of ToSRV in 'Mariana' hybrid tomatoes and increased the yield of plants that received inoculations at more advanced phenological stages. However, the activated mechanism still needs to be elucidated and experiments with other hybrids are needed to confirm the effect on other genotypes. These results may help farmers to manage ToSRV in the field, in tomato plantations.

\section{Conclusion}

The 'Mariana' hybrid tomato (Solanum lycopersicum), coinfected late in the growth cycle $(45,60$, and 75 days after transplanting) with Tomato severe rugose virus and Tomato chlorosis virus, has greater plant yield and better fruit quality when subjected to the pretreatment with pyraclostrobin + metiram $\left(3 \mathrm{~g} \mathrm{~L}^{-1}\right)$ and boscalid $(0.3$ $\mathrm{g} \mathrm{L}^{-1}$ ), followed by biweekly spraying of the seedlings with pyraclostrobin + metiram $\left(4 \mathrm{~g} \mathrm{~L}^{-1}\right)$, and has a lower concentration of Tomato severe rugose virus than plants that received inoculations earlier in the growth cycle.

\section{Acknowledgments}

To Coordenação de Aperfeiçoamento de Pessoal de Nível Superior (Capes), for the scholarschip granted.

\section{References}

AGRODEFESA. Agência Goiana de Defesa Agropecuária. Instrução Normativa $\mathbf{n}^{\mathbf{0}}$ 6/2011. Institui ações e medidas fitossanitárias que visem o controle de Mosca Branca (Bemisia tabaci, biótipo B) e do geminivírus no estado de Goiás. 2011. Available at: <http://www.sgc.goias.gov.br/upload/ arquivos/2016-07/in-06_11.pdf >. Accessed on: Oct. 312016.

AKHTAR, K.P.; HUSSAIN, M.; KHAN, A.I.; HAQ, M.A.; IQBAL, M.M. Influence of plant age, whitefly population and cultivar resistance on infection of cotton plants by cotton leaf curl virus (CLCuV) in Pakistan. Field Crops Research, v.86, p.15-21, 2004. DOI: 10.1016/S0378-4290(0300166-7.

BALAMURALIKRISHNAN, M.; DORAISAMY, S.; GANAPATHY, T.; VISWANATHAN, R. Sugarcane Mosaic Virus infection progress in relation to age of sugarcane. Sugar Tech, v.5, p.21-24, 2003. DOI: 10.1007/BF02943759.

BARBOSA, J.C.; BARRETO, S. da S.; INOUE-NAGATA, A.K.; REZENDE, J.A.M. Characterization and experimental host range of a Brazilian tomato isolate of Tomato severe rugose virus. Journal of Phytopathology, v.159, p.644-646, 2011. DOI: 10.1111/j.1439-0434.2011.01817.x.

BASTÍAS, A.; LÓPEZ-CLIMENT, M.; VALCÁRCEL, M.; ROSELLO, S.; GOMEZ-CADENAS, A.; CASARETTO, J.A. Modulation of organic acids and sugar content in tomato fruits by an abscisic acid-regulated transcription factor. Physiologia Plantarum, v.141, p.215-226, 2011. DOI: http://dx.doi.org/10.1111/ j.1399-3054.2010.01435.x.

DEVELEY-RIVIÈRE， M.-P.; GALIANA， E. Resistance to pathogens and host developmental stage: a multifaceted relationship within the plant kingdom. New Phytologist, v.175, p.405-416, 2007. DOI: 10.1111/j.1469-8137.2007.02130.

DOVAS, C.I.; KATIS, N.I.; AVGELIS, A.D. Multiplex detection of criniviruses associated with epidemics of a yellowing disease 
of tomato in Greece. Plant Disease, v.86, p.1345-1349, 2002. DOI: 10.1094/PDIS.2002.86.12.1345.

ESASHIKA, D.A.S.; MICHEREFF-FILHO, M.; BASTOS, C.S.; INOUE-NAGATA, A.K.; DIAS, A.M.; RIBEIRO, M.G.P.M. Suscetibilidade de adultos de Bemisia tabaci biótipo B a inseticidas. Horticultura Brasileira, v.34, p.189-195, 2016. DOI: 10.1590/S0102-053620160000200007.

FAGAN, E.B.; DOURADO NETO, D.D.; VIVIAN, R.; FRANCO, R.B.; YEDA, M.P.; MASSIGNAM, L.F.; OLIVEIRA, R.F. de; MARTINS, K.V. Efeito da aplicação de piraclostrobina na taxa fotossintética, respiração, atividade da enzima nitrato redutase e produtividade de grãos de soja. Bragantia, v.69, p.771-777, 2010. DOI: 10.1590/S0006-87052010000400001.

FERREIRA, D.F. Sisvar: a computer statistical analysis system. Ciência e Agrotecnologia, v.35, p.1039-1042, 2011. DOI: 10.1590/ S1413-70542011000600001.

GUIMARÃES, L.R.P.; SOLER, J.M.P.; LIMA, G.P.P.; PAVAN, M.A. Polyamines in tomato plants grown during an incidence of tospovirus exposure. European Journal Plant Pathology, v.140, p.701-709, 2014. DOI: 10.1007/s10658-014-0490-X.

HAIBLE, D.; KOBER, S.; JESKE, H. Rolling circle amplification revolutionizes diagnosis and genomics of geminiviruses. Journal of Virological Methods, v.135, p.9-16, 2006. DOI: 10.1016/j. jviromet.2006.01.017.

HORWITZ, W.; CHICHILO, P.; REYNOLDS, H. (Ed.). Official methods of analysis of the Association of Official Analytical Chemistry. $11^{\text {th }}$ ed. Washington: AOAC, 1970. 1015p.

HUTTON, S.F.; SCOTT, J.W.; SCHUSTER, D.J. Recessive resistance to tomato yellow leaf curl virus from the tomato cultivar tyking is located in the same region as Ty-5 on chromosome 4. Hortscience, v.47, p.324-327, 2012.

INOUE-NAGATA, A.K.; ALBUQUERQUE, L.C.; ROCHA, W.B.; NAGATA, T. A simple method for cloning the complete begomovirus genome using the bacteriophage $\varphi 29$ DNA polymerase. Journal of Virological Methods, v.116, p.209-211, 2004. DOI: 10.1016/j.jviromet.2003.11.015.

INOUE-NAGATA, A.K.; LIMA, M.F.; GILBERTSON, R.L. A review of geminivirus (begomovirus) diseases in vegetables and other crops in Brazil: current status and approaches for management. Horticultura Brasileira, v.34, p.8-18, 2016. DOI: 10.1590/S0102-053620160000100002.

ITAKO, A.T.; TOLENTINO JÚNIOR, J.B.; SILVA JÚNIOR, T.A.F. da; SOMAN, J.M.; MARINGONI, A.C. Chemical products induce resistance to Xanthomonas perforans in tomato. Brazilian Journal of Microbiology, v.46, p.701-706, 2015. DOI: 10.1590/ S1517-838246320140177.

JADOSKI, C.J.; RODRIGUES, J.D.; SORATTO, R.P.; SANTOS, C.M. dos; RIBEIRO, E. Ação fisiológica da piraclostrobina na assimilação de $\mathrm{CO}_{2}$ e enzimas antioxidantes em plantas de feijão condicionado em diferentes tensões de água no solo. Irriga, v.20, p.319-333, 2015. DOI: 10.15809/irriga.2015v20n2p319.
KOZLOWSKI, L.A.; SIMÕES, D.F.M.; SOUZA, C.D. de; TRENTO, M. Physiological effects of strobilurins F 500® in the growth and yield of bean. Revista Acadêmica Ciências Agrárias e Ambientais, v.7, p.41-54, 2009.

KUS, J.V.; ZATON, K.; SARKAR, R.; CAMERON, R.K. Agerelated resistance in arabidopsis is a developmentally regulated defense response to Pseudomonas syringae. The Plant Cell, v.14, p.479-490, 2002. DOI: 10.1105/tpc.010481.

MACEDO, M.A.; BARRETO, S.S.; HALLWASS, M.; INOUENAGATA, A.K. High incidence of Tomato chlorosis virus alone and in mixed infection with begomoviruses in two tomato fields in the Federal District and Goiás state, Brazil. Tropical Plant Pathology, v.39, p.449-452, 2014. DOI: 10.1590/S198256762014000600005.

POLSTON, J.E.; DE BARRO, P.; BOYKIN, L.M. Transmission specificities of plant viruses with the newly identified species of the Bemisia tabaci species complex. Pest Management Science, v.70, p.1547-1552, 2014. 24p. DOI: 10.1002/ps.3738.

RANGEL, Y.; GARRIDO, M.J.; MONTEVERDE, E. Efecto del virus del mosaico enanizante del maíz raza venezolana sobre algunas características biométricas asociadas al rendimiento de três cultivares de sorgo. Fitopatologia Venezolana, v.9, p.36-41, 1996.

ROJAS, M.R.; GILBERTSON, R.L.; RUSSEL, D.R.; MAXWELL, D.P. Use of degenerate primers in the polymerase chain reaction to detect whitefly-transmitted geminiviruses. Plant Disease, v.77, p.340-347, 1993. DOI: 10.1094/PD-77-0340.

SKANDALIS, N.; DIMOPOULOU, A.; BERI, D.; TZIMA, A.; MALANDRAKI, I.; THEOLOGIDIS, I. Effect of pyraclostrobin application on viral and bacterial diseases of tomato. Plant Disease, v.100, p.1321-1330, 2016. DOI: 10.1094/PDIS-10-15-1216-RE.

TREJO-SAAVEDRA, D.L.; GARCÍA-NERIA, M.A.; RIVERABUSTAMANTE, R.F. Benzothiadiazole (BTH) induces resistance to Pepper golden mosaic virus (PepGMV) in pepper (Capsicum annuum L.). Biological Research, v.46, p.333-340, 2013. DOI: 10.4067/S0716-97602013000400004.

UDAYASHANKAR, A.C.; NAYAKA, C.S.; ARCHANA, B.; NAYAK, U.; NIRANJANA, S.R.; PRAKASH, H.S. Strobilurins seed treatment enhances resistance of common bean against Bean common mosaic virus. Journal of Phytopathology, v.160, p.710-716, 2012. DOI: 10.1111/jph.12006.

WINTERMANTEL, W.M.; WISLER, G.C. Vector specificity, host range, and genetic diversity of Tomato chlorosis virus. Plant Disease, v.90, p.814-819, 2006. DOI: 10.1094/PD-90-0814.

ZENEBON, O.; PASCUET, N.S.; TIGLEA, P. (Coord). Métodos físico-químicos para análise de alimentos. São Paulo: Instituto Adolfo Lutz, 2008. 1020p.

ZHANG, M.; YUAN, B.; LENG, P. The role of ABA in triggering ethylene biosynthesis and ripening of tomato fruit. Journal of Experimental Botany, v.60, p.1579-1588, 2009. DOI: 10.1093/ jxb/erp026.

Received on August 26, 2016 and accepted on November 24, 2016

Pesq. agropec. bras., Brasília, v.52, n.6, p.435-442, jun. 2017

DOI: 10.1590/S0100-204X2017000600007 